\title{
Motivation, morals and justice: discourses of worklessness in the welfare reform green paper
}

\author{
Richard Crisp* \\ Sheffield Hallam University
}

\section{Summary}

New Labour's recent green paper on welfare reform - No one written off: reforming welfare to reward responsibility - outlines new plans for tackling worklessness. The proposals centre on extending conditional forms of welfare that mandate participation in work-related activities to cover most of the workless population. This article considers the way in which discourses of workless are deployed in the green paper to make the case for reform. It asserts that the proposals are underpinned by three central claims regarding the individual causes of worklessness ('motivation'), the responsibilities of citizens to seek work ('morals') and the social benefits of working ('justice'). These claims are used to legitimise plans for accelerating the roll-out of supply-side welfare-to-work programmes that seek to improve the employability of the workless. This article contends, however, that these claims are undermined by competing arguments that worklessness is as much a function of labour demand in terms of a lack of suitable jobs. It identifies the need to ground welfare reform in a sober assessment of labour market conditions if it is to provide more equitable forms of assistance to ensure 'no-one [is] written off'. The paper concludes by suggesting that the failure of policymakers to acknowledge these arguments can be attributed to the role these discourses play in validating conditional forms of welfare that enforce the takeup of unattractive work.

Keywords: New Labour, welfare, workfare, worklessness.

\section{Introduction}

I can well remember the times when it was assumed that everyone unemployed was so through his own fault...Today unemployment is realised to be in the majority of cases a misfortune due to the maladjustment of the economic machine instead of a failure of character. (Clement Atlee cf. Grieve Smith, 2005) 
p. 173. Motivation, morals and justice: discourses of worklessness in the welfare reform green paper

For those who have been unemployed for a long period or who are thought to be playing the system, we will test strong measures - including full-time work in return for benefits. There should be no choice between working and a life on benefits. If people can work and there are opportunities available to them, they will be expected to do so. (Welfare reform green paper, DWP, 2008: 19)

New Labour's recent green paper on welfare reform - No one written off: reforming welfare to reward responsibility - outlines proposals which, it claims, will complete a 'transformation' (DWP, 2008a: 19) from a passive to an active welfare state. The stated aim is to restructure the benefit system to 'maximise[] the numbers in employment and minimise[] the numbers on benefit' (2008a: 5). This is to be achieved by tightening levels of conditionality for those claiming Jobseekers Allowance by 'requiring them to do more the longer they claim' (2008a: 5) with mandatory 'work for benefit' schemes for those who remain unemployed after two years. At the same time, compulsory participation in workrelated activities will be extended to sections of the economically inactive population that were hitherto exempt. All but the most sick and disabled claimants of incapacity benefits as well as lone parents whose youngest children is over five will now be expected to engage in a range of prescribed activities including work-focused interviews, job search and compulsory skills checks and training. Alongside plans to raise levels of conditionality, the paper outlines intentions to increase funding for training and in-work support for disabled people. The paper presents this combination of mandatory activity and increased assistance as 'a simple deal: more support, more responsibility' (2008a: 5).

This article critically examines the welfare reform green paper. Central to this critique is the notion that the case for reform made in No one written off (NOWO) can be usefully understood as a discourse in the sense of 'sets of interrelated concepts [that] act together as a matrix through which we understand the social world' (Levitas, 2005: 3). Discourses are important as they 'govern[] the paths of action which appear to be open to us...a discourse constitutes ways of acting in the world, as well as a description of it. It both opens up and closes down possibilities for action for ourselves' (ibid.). One implication of this is that unless the underlying discursive premise of a particular policy is identified, there is a risk of being swept along by its internal logic without countenancing alternative possibilities that may have been 'closed down'. For this reason, this article seeks to identify the 'interrelated concepts' underpinning the green paper as a prerequisite for creating a critical space in which to consider the strengths and limitations of the proposed reforms. In doing so, it attempts to avoid becoming caught up in the minutiae of policy detail and should not be considered an exhaustive response to the proposals.

The article identifies three central claims within the green paper that are deployed to make the case for reform. The first element is an affirmation of the individual causes of worklessness ('motivation') with a lack of employability rather than a lack of employment seen to account for individuals not working. This is underpinned by a narrative of past policy success which marshals evidence of the impact of previous rounds of supply-side welfare-to-work programmes, most notably the New Deal, to validate proposals to extend employment programmes to include large sections of the economically inactive population. The second element of the case for reform is a philosophical position ('morals') on the nature of the relationship between the individual and the state. Centring on a notion of contract, it invokes the notion of 'rights and responsibilities' where the right to benefit is conditional on claimants fulfilling a reciprocal duty to look for work. The third and final element of the case for reform is a series of claims made about the financial and social 
benefits of work compared to the negative experience of being out of work that, by extension, creates an imperative for the government to ensure that everyone is given the opportunity to work ('justice'). In combination, these three claims of motivation, morals and justice are interwoven to create an apparently irresistible case for reform.

This article, however, questions the irreducible logic of welfare reform presented in the green paper. It suggests the proposals are dependent on a flawed and selective combination of discourses that neglect concerns about the quantity and quality of work in the UK economy. In terms of quantity, the green paper fails to acknowledge the uneven geography of employment opportunity with welfare-to-work programmes performing least well in the former industrial regions with less buoyant labour markets (Beatty et al., 2000; Sunley et al., 2001; Fothergill and Wilson, 2007). This undermines the notion that worklessness is largely a problem of employability and that supply-side welfare-to-work programmes remain the most efficient mechanism for tackling worklessness. Equally, the green paper fails to engage fully with evidence about the poor quality of work in the lower end of the labour market (Jessop, 2002; McDowell, 2003; Gray 2004). This challenges arguments relating to the financial and social benefits of paid employment. A final implication of both concerns about the quantity and quality of work is that the notion of contract can surely be contested if the 'responsibility' to find work is constrained by conditions in the UK economy. The obligations of claimants cannot simply float free of the availability or quality of work. The paper concludes that the government's lack of willingness to engage with these debates reflects the role that discourses of welfare reform play in legitimising conditional forms of welfare that ensure a ready supply of labour for precarious and contingent work (Lash, 1994; Peck, 2001; Jessop, 2002).

The article begins by identifying the key features of welfare reform under New Labour since 1997. It continues by examining the proposals contained in NOWO and seeks to identify the key discursive elements deployed to make the case for reform. The section which follows critically considers these arguments in the light of evidence regarding conditions in the UK economy. The paper concludes with some thoughts on the function this discourse plays in legitimising welfare reform and the possibilities for shaping a more just welfare settlement.

\section{Ten years of tackling worklessness: New Labour's employment policy}

Welfare reform lies at the heart of the New Labour project, with NOWO constituting the latest of a series of reforms aimed at reducing worklessness (see DWP, 2002, 2004, 2006). These reforms have comprised two key components: a series of reforms to the tax and benefit system to 'make work pay' alongside employment programmes designed to integrate the workless into the labour market (see Table 1 below). As a number of commentators have noted, these policy developments have been heavily influenced by innovations in employment policy in the US although the UK system remains far less punitive as well as less focused on lone parents (Midgley et al., 2008).

Looking firstly at the 'make work pay' agenda, the National Minimum Wage and the Working Family Tax Credit (now Working Tax Credit) were introduced in 1999 to increase the wages available to the lowest paid workers, thereby providing greater financial incentives for those on benefits to return to work. These reforms have been accompanied by the roll-out of two key welfare-to-work programmes. The first of these is the New Deal suite of schemes introduced in the first term of the New Labour government that primarily 
targets claimants of Jobseekers Allowance. Whilst the different New Deals vary in terms of sequencing, levels of conditionality and the type of support on offer, they tend to mandate a period of more intensive job search followed by participation in work-related activities such as training, education or some form of work experience. A second, later phase of welfare-to-work reform has seen attention shift onto claimants of incapacity benefits (mainly Incapacity Benefit and disability-related Income Support) with the introduction of Pathways to Work in 2003. This marked a fundamental change in the structure of the benefit system by extending conditional forms of welfare-to-work from jobseekers to the economically inactive. Under the programme, individuals making a new claim for incapacity benefits are required to attend 'Work Focused Interviews' (WFIs) to discuss options for returning to employment. Rehabilitative support is made available in the form of Condition Management Programmes whilst a Return to Work Credit of up to $£ 40$ a week is available for one year for those who find employment through the scheme.

Table 1: Key welfare reforms under New Labour

\begin{tabular}{llcl} 
Type of reform & Policy / programme & Date & Comment \\
\hline $\begin{array}{l}\text { 1. Reforms to tax } \\
\text { and benefit } \\
\text { system }\end{array}$ & $\begin{array}{l}\text { National Minimum } \\
\text { Wage }\end{array}$ & 1999 & \\
& $\begin{array}{l}\text { Working Families' Tax } \\
\text { Credit }\end{array}$ & 1999 & $\begin{array}{l}\text { Replaced the Family Credit in } 1999 . \\
\text { Working Tax Credit }\end{array}$ \\
& 2003 & $\begin{array}{l}\text { Replaced Working Family Tax Credit in } \\
\text { order to extend eligibility to low-paid } \\
\text { individuals living in households without } \\
\text { children. }\end{array}$ \\
\hline
\end{tabular}

\section{Employment programmes \\ New Deal for Young People (NDYP)}

New Deal 25 plus (ND25+)

New Deal for Lone Parents (NDLP)

New Deal for Partners

New Deal 50 plus

New Deal for Disabled People (NDDP)
1998 Targets young people aged 18-24 claiming JSA for six months or more.

1998 Targets long-term unemployed (claiming JSA for at least 18 of the past 21 months) aged 25-49.

1998

1998 Provides back-to-work support for partners of individuals claiming benefits.

2000 Targets the unemployed and economically inactive aged over 50 claiming benefits for over six months.

2001 Targets claimants of Incapacity Benefit and other disabled people out of work.

\begin{tabular}{ll} 
Pathways to Work 2003 & $\begin{array}{l}\text { Piloted in } 2003 \text { and rolled out } \\
\text { nationally by } 2008 \text {. Targets all new } \\
\text { claimants of Incapacity Benefit. }\end{array}$ \\
\hline Sources: Dickenson and McKnight (2008); DWP (2008d) &
\end{tabular}


These policies to tackle worklessness have been underpinned by three key claims. The first concerns the economic assumption that worklessness is a supply-side phenomenon best tackled through a focus on improving the employability of those out of work. As Theodore (2007) explains, proponents of this view focus not on the availability of jobs but on the lack of qualifications, skills and motivation that prevents the workless from accessing employment opportunities (see also Jessop, 2002). This lack of employability is seen to create bottlenecks in the labour market due to the presence of large numbers of workless adults who 'cease to performing [their] market clearing function of creating downward pressures' on wages in a way that would encourage employers to create jobs (Theodore, 2007: 929). Explicit within this conception of worklessness is the notion that 'the causes of unemployment are...conceived in individualistic and behavioural terms' (Peck and Theodore, 2000: 729). That is to say, the workless at are at least partially responsible for their own predicament. The logic of this reasoning invites 'calls for supplyside interventions towards activating underemployed segments of the labour force through training, job-readiness programming and unemployment benefit reforms that encourage (and increasingly compel) rapid entry into work' (Theodore, 2007: 929).

The government's adherence to supply-side economics is evident in policy statements such as the view presented in the HM Treasury paper on 'Full Employment in Every Region' that 'the worst concentrations of worklessness are in very small defined areas and are caused not by a lack of jobs but by people living in these areas being unable to compete successfully for the vacancies available' (HM Treasury, 2003: 46). This underlines the assumption that it is not the availability of jobs so much as the inability of jobseekers to access available work that creates worklessness. That this is, in part, regarded as a behavioural problem is also evident in pronouncements on the existence of a "culture of worklessness' or a 'poverty of aspirations' (HM Treasury, 2003: 46) as well as 'a workless class... playing no role in the formal economy, dependent on benefits and the black economy' (Blair, Aylesbury Estate Speech, June 1997). This form of economic rationale laced with moral invective has led to claims that New Labour's position can be conceived of as 'supply-side fundamentalism' (Peck and Theodore, 2000: 729).

The second claim underpinning New Labour's policies on tackling worklessness is a moral discourse on 'rights and responsibilities' that has pervaded official statements and policies on welfare reform from the mid-1990s (DSS, 1998: 1; DWP, 2007: 2; see also Levitas, 2005: 121). Drawing on the communitarian ideals of social thinkers such as Amitai Etzioni and Anthony Giddens, the government has readily embraced the notion that 'postwar democracy was too eager to extend the scope of individual rights without any corresponding concern with the responsibilities attached to rights' (Driver and Martell, 1998:130). One effect of this is to eschew the model of rights-based entitlement to welfare enshrined in the Titmuss paradigm in preference for a 'morally prescriptive, conservative' (Driver and Martell, 1998: 177) interpretation of communitarian ideals that validates conditional forms of welfare. Accordingly, there is some degree of obligatory work-related activity embedded within nearly all the New Deal schemes as well as the more recent Pathways to Work Programme (see DWP 2008b for a fuller account).

The third claim that features strongly in policy statements on welfare reform concerns the perceived benefits of work. As Levitas (2005) has shown in her work on social exclusion, the government firmly adheres to a notion of work as the primary route to social inclusion. This is evident in a speech delivered by Harriet Harman on opening the new Centre for Analysis of Social Exclusion in 1999: 
Work is the only route to sustained financial independence...Work is not just earning a living. It is a way of life...Work helps fulfils our aspirations - it is the key to independence, self-respect and opportunities for advancement... Work brings a sense of order that is missing from the lives of many unemployed young men. Work provides access to social networks. (cf. Levitas, 2005:151)

In this respect, work is seen to provide financial independence as well as number of non-pecuniary benefits that are 'missing' from the lives of those without work. Within this rubric, extending employment opportunity to the workless becomes essential as it provides a pathway out of exclusion experienced by the non-working population.

In summary, these three claims regarding the individual causes of worklessness ('motivation'), obligations to work ('morals') and the benefits ascribed to work ('justice') have been deployed consistently over the last ten years to validate the government's approach to tackling worklessness. That is to say, these discourses function to legitimise supply-side policy interventions underpinned by elements of conditionality to encourage benefit claimants to fulfil their responsibilities to the state, whilst at the same time extending opportunities for inclusion. As the section which follows illustrates, these discourses remain very much evident in the recently published green paper.

\section{No-one Written Off: The welfare reform green paper}

The welfare reform green paper is an ambitious document that outlines proposal to reform all key non-working benefits including Jobseekers Allowance (JSA), Incapacity Benefit (IB) and Income Support (IS) so that almost all claimants will now be subject to some form of requirement to look for work. As the document itself states, 'Quite simply we want everyone who can work to work...That means everyone, other than the most severely disabled, carers or parents with young children, should look for work, train for work or take available work' (DWP, 2008a: 3, 30). This will impact most severely on the two groups who, until now, have largely been exempt from explicit requirements to look for work: lone parents with children under 16 and existing claimants of IB. The ultimate goal is to achieve what is described as a 'social revolution' (2008a: 12) by raising employment rates to $80 \%$, the highest of any major industrialised country.

Whilst not wishing to reproduce the proposals in full, it is important to note the key reforms outlined in the proposal (see Table 2 below). As explained above, the intention here is not to provide a detailed response to each proposal but to attempt to analyse the way in which discourses of worklessness have shaped these policy responses. In this respect, it is notable that the green paper draws heavily upon the three key claims that have characterised New Labour's approach to tackling worklessness over the last 10 years. 
Table 2: Key proposals in the welfare reform green paper

\section{Category Changes to benefit rules and job seeking requirements}

JSA claimants A tougher JSA sanctions regime including 'fast-tracking' people who have a recent history of long-term unemployment or 18 year olds who spent the previous six months out of education, training or work onto a six month intensive job search phase.

A programme of full-time, community-based work experience - 'work for your benefit' - to improve 'work habits and employability' for those who have not found work within two years.

Lone parents An obligation to get skills training when the youngest child children turns five and to look for work under the JSA regime when the youngest child is aged seven.

IB claimants All new and existing IB clients will be transferred onto a new benefit called the Employment and Support Allowance (ESA) between 2009 and 2013, with the majority of ESA claimants mandated to attend Work Focused Interviews and participate in Pathways to Work.

Source: DWP 2008a

Looking firstly at the economic assumptions underpinning the green paper, there is a recurrent theme that worklessness is, in part, a problem of employability with individuals lacking the motivation, skills or aptitude to compete successfully in the labour market. This emerges in comments concerning policies to tackle individuals 'thought to be playing the system' (2008a: 19) and 'the idea that people could sit at home and claim benefits' (2008a: 11). Furthermore, under the Work Skills agenda, workless individuals will now be compelled to undergo training or skills development, thus reinforcing a sense that individuals need to be mandated to make themselves job-ready. These supply-side arguments are reaffirmed through a narrative of past policy success which asserts that a platform of 'macroeconomic stability' combined with 'innovative employment programmes' (2008a: 26) such as the New Deal and reforms to the tax and benefits system have led to a number of 'improved outcomes' (2008a: 27) since 1997. These include one million fewer people on IS, JSA and IB than in 1997; claimant unemployment at near its lowest level for 30 years; and a 12.5 percentage point increase in the employment rate of lone parents. Thus a combination of supply-side reasoning and the knowledge from 'a decade of lessons about what works' (2008: 11) are deployed as evidence to support accelerating the roll-out of supply-side reforms.

The second claim that re-emerges is the strong emphasis on rights and responsibilities, with the green paper advocating a 'something for something' approach' (2008a: 11) based on 'a simple deal: More support, more responsibility' (2008a: 7). Once more, the notion of reciprocity is invoked through assertions of a '( $n$ )eed for a contract between the individual and society, where the individual's right to support comes in exchange for taking clear steps to improve their own circumstances (2008a: 23). This translates into calls for '[t]ougher sanctions for those who fail to take steps to get back into work or refuse to take a job' (2008: 19). As outlined above, this includes 'toughening' (2008a: 37) the JSA sanctions regime and, more controversially, requiring claimants who have been unable to 
find work within two years to participate in some form of "community-based work for benefit scheme' (2008a: 37) more commonly known as 'workfare' (see Peck, 2001, Lodomel, 2004). Overall, the intention to impose 'tough sanctions' and 'tougher responsibilities' (2008a: 5, 14) marks a considerable ratcheting up of the degree of conditionality to which nearly all benefit recipients are exposed.

The third and final discursive element of New Labour's approach to tackling worklessness that reappears in the green paper is the assertion that work delivers a multitude of social and economic benefits:

Paid work is the route to independence, health and well-being for most people. Work promotes choice, supports an inclusive society and increases community cohesion (DWP, 2008a: 25).

As such, work is seen to provide benefits both to individuals and to the communities in which they live. This is further supported through reference to 'a compelling body of medical evidence that work generally helps, rather than hinders, health and recovery' (DWP, 2008a: 66) including Dame Carol Black's (2008) report 'Working for A Healthier Tomorrow'. Overall, the green paper remains firmly wedded to the notion that work is an essential source of personal enrichment.

In this way, the green paper combines the same discursive elements that have infused New Labour's welfare reforms since coming to power. These relate to the individual causes of worklessness, moral invocations of the responsibility to work and claims of social justice in opening up opportunities to employment so that workless individuals can access the social rewards of employment. In tandem, they seek to create an irrefutable case for accelerating the roll-out of supply-side employment programmes to include nearly the entire workless population. Nonetheless, as the following section illustrates, concerns regarding the ability of the UK economy to deliver sufficient quantities of suitable work present significant challenges to the case made for welfare reform within the green paper.

\section{Never mind the labour market: The neglect of the economic context}

New Labour's approach to tackling worklessness has sustained fundamental critiques relating to its inability or unwillingness to address conditions in the UK labour market. In particular, it has been claimed that the supply-side emphasis of employment policy has failed to address shortfalls in the quantity of work and shortcomings in the quality of work available. In terms of the quantity of work, there is ample evidence that de-industrialisation has created a persistent legacy of weak labour markets in some parts of the UK. Beatty et al. (2000) have argued, for example, that regional differences in employment rates conceal forms of 'hidden unemployment'. This consists of individuals with health problems who lost jobs in the industrial shake-out in 1980s and 1990s and, finding themselves unable to find work, were legitimately diverted onto incapacity benefits. It is now estimated that as many as 1.1 million out of the headline total of 2.7 million incapacity benefits claimants could reasonably be expected to find work in conditions approximating a full economy (Beatty and Fothergill, 2006). This concentration of 'hidden unemployment' in the former industrial heartlands suggests that some regional economies have not fully recovered from the fallout of deindustrialisation, a conclusion also reached by a number of other researchers (see also Turok and Edge, 1999; Webster, 2006; Theodore, 2007). 
Crucially, a shortage of jobs has ramifications for the effectiveness of supply-side employment programmes. As Sunley et al.'s (2001) research on the link between the uneven geography of labour demand and the effectiveness of the New Deal for Young People has demonstrated, the programme achieves far fewer sustainable job placements and greater churn in the least buoyant labour markets such as the north-east. Similar concerns have been expressed more recently by Fothergill and Wilson (2007) about the ability of the Pathways to Work programme to achieve the government's target of reducing the number of IB claimants by one million. They estimate the target will be missed given lagging levels of labour demand in the North, Scotland and Wales. This is all the more disconcerting in view of the recent rise in ILO unemployment by 81,000 over the quarter to July 2008 to reach 1.72 million and warnings of a 'severe recession' (Hopkins, 2008) in the UK by 2009 given by one Bank of England Monetary Policy Committee member.

This evidence on the relationship between the uneven geography of both employment opportunity and the impact of welfare reform presents a number of challenges to the current direction of policy. Firstly, it undermines the supply-side insistence that worklessness is not related to a lack of labour demand. Indeed, as economic conditions rapidly deteriorate, this view seems ever more misplaced. Secondly, it challenges the assumption that worklessness is, at least in part, a reflection of the lack of willingness or ability of the workless to compete for employment. Employability cannot be the sole explanation if there are insufficient jobs to compete for. Thirdly, the moral justification for enforcing 'rights and responsibilities' through conditionality is weakened if the worklessness is regarded to be, to some degree, a function of a shortage of jobs. Individuals cannot be held culpable for failing to avail of opportunities that do not exist. This is particularly the case for the most marginalised jobseekers at the "back of the queue for jobs' (Beatty and Fothergill, 2003: 129) who are more likely to face employer discrimination in weak labour markets.

In addition to concerns over the level of demand, a number of observers have also expressed fears about the quality of work that has emerged as a result of economic restructuring over the last three decades. One consequence of the decline of traditional industries and manufacturing has been a corresponding fall in reasonably well-paid work for those with no skills. In its place, the number of low-paid jobs - the 'donkey work' (Warhurst and Thompson, 1998:5), 'junk jobs' (Lash, 1994) or 'poor work' (McDowell, 2003: esp. chapter 2) of the UK economy - has increased over the last 25 years. A recent TUC report (2008) estimated that there as many as two million 'vulnerable workers' in 'precarious work' that is insecure, low-paid and, in the case of agency workers, lacks entitlement to sick pay, paid holidays and pension contributions that permanent employees enjoy. At the same time many of the low-skilled jobs created in the period of economic expansion that began in the 1990s not paying enough to support a family, thereby producing a new category of 'working poor' (McDowell, 2003:48; see also UK Parliament, 1999: 6; Alcock et al., 2003:243). Indeed, research indicates that six in ten poor households in the UK (57 per cent) have someone in work, demonstrating that '[w]hile work is undoubtedly the surest route out of poverty, it is far from an inevitable one' (Cooke and Lawton, 2008:5).

This evidence on the quality of work in the lower end of the labour market presents a number of challenges to the proposals in the green paper. Firstly, and perhaps most significantly, it destabilises claims regarding the benefits provided by paid work. In financial terms, it may remain true that worklessness increases the 'risk of poverty' (DWP, 2008a: $65)$ but, equally, it does not follow that entering employment entirely negates that risk. In 
addition, it is not clear that low-paid, low-skilled work will invariably deliver the emotional and psychological benefits such as 'independence, health and well-being' (DWP, 2008a:25) associated with employment in the green paper. A second implication is that concerns about the quality of work expose the profoundly unequal nature of the contract which, policymakers claim, underpins the welfare system. As the Child Poverty Action Group (CPAG) observed in their response to the Green Paper, employers are the 'black hole' in ensuring that no-one is written off '(CPAG, 2008):

The green paper gives great attention to increasing individual responsibility but ignores the responsibilities of employers to open up access to decent jobs. Poorly paid jobs and inflexible employers do nothing to support moves back into employment and may undermine family life. Bad employers must now be the urgent target for welfare reform. (CPAG, 2008)

This illustrates the difficulty in presenting welfare as a 'contract' if responsibilities are not apportioned evenly.

Granted, it would be misleading to imply that the green paper does express any concerns over the quality of work as it does discuss ways of improving the sustainability of job outcomes and the ability of jobseekers to access more highly skilled work through training. In order to support more sustainable forms of employment, providers contracted to run services as part of the Flexible New Deal will receive fifty per cent of their payment on the basis of jobs sustained by clients for longer than 13 weeks, with a further thirty per cent awarded if employment is sustained for 26 weeks (Mulheirn and Menne, 2008). This is a welcome recognition that a 'work-first' (Peck, 2000) approach to welfare is liable to lead to high levels of churn as participants are placed in temporary or unattractive work unless sustainability targets are built into contracts. Concerns remain, however, over the appropriateness of the 13 and 26 week targets as measures of sustainable work as many job starters leave employment after they have been in work for 26 weeks (Mulheirn and Menne, 2008: 15). This raises question marks over the extent to which the contractual arrangements proposed for the Flexible New Deal will be effective in promoting more sustainable outcomes.

In terms of skill development, NOWO states that "[o]ur customers should - and do aspire to more than low-skilled, low-paid jobs. More and more opportunities are available in higher skill sectors so we are reforming the system to make it easier for people to access and benefit from skills development' (2008a: 118). This is to be achieved, in part, through the development of the Work Skills agenda (see DWP and DIUS, 2008c) which will trial joint commission approaches that bring together the Learning and Skills Council's resources with those of the DWP's Flexible New Deal. The intention is to remove the confusion caused by the current separation of services for those looking for work and those looking to develop skills and engage in training. Yet whilst support for skill development is, of course, welcome, it is far from evident that all job seekers will invariably benefit from such initiatives given the considerable constraints marginalised individuals face. As Dean has noted:

[the] assumption is that investment in a person's skills and training may produce a return that will benefit both the welfare of the individual and the productivity of the economy. This is, however, unduly individualistic in that the ability to invest in education and skills training and the effectiveness of the outcomes are subject to the 
p. 182. Motivation, morals and justice: discourses of worklessness in the welfare reform green paper

wider social context, including the effects of poverty, class background, parental and peer group influences. (2007: 585)

With this in mind, the green paper's emphasis on occupational progression through individual development shows little recognition of the formidable social barriers many individuals with low skills face in taking part in training or education. It also neglects more immediate and realisable possibilities for improving the terms and conditions attached to low-skilled work in preference for a somewhat illusory invocation that jobseekers bypass the lower end of the labour market altogether. Furthermore, there is a clear tension between asserting the importance of providing opportunities for jobseekers to access higher-skilled work whilst imposing forms of conditionality that require claimants to accept 'any suitable employment' (DWP, 2008a: 39). Such a compulsion would lock some jobseekers into precisely those 'low-skilled, low-paid jobs' that the green paper appears to condemn. This is not joined-up policy-making.

To conclude this section, it is worth reflecting on what a more equitable welfare reform project might look like. First, it is important to emphasise that the critique outlined above is not a wholesale rejection of the proposals in the green paper. There is a long tradition of research on the negative impact of job loss as well as the benefits of work (see Jahoda, 1993/72; Warr, 1987; Gallie et al., 1995). A lack of employability is undoubtedly an issue for many workless individuals and a lack of skills, qualifications and confidence can be highly damaging for the labour market prospects of the workless (Alcock et al., 2003; McDowell, 2003; Gray, 2004). The mistake, however, is to use these concerns to legitimate implementing increasingly conditional forms of welfare-to-work that appear to float free of labour market conditions. A more just approach would surely recognise the shortfalls in labour demand as well as the shortcomings in the quality of work available. This suggests that a return to interventions to increase the level of employment is an urgent task, especially in view of the current economic situation. The resulting rebalance away from the present 'supply-side fundamentalism' (Peck and Theodore, 2000: 729) would acknowledge, as Theodore (2007: 928) argues that, 'supply-side measures like the New Deal are incapable of counteracting problems of entrenched structural unemployment without reflationary measures designed to increase the number of jobs available in distressed regions'. At the same time, issues of job quality must be tackled head-on as the tentative proposals to address sustainability and a lack of skills are both inadequate and ill-conceived as measures to improve conditions in the lower reaches of the labour market. Only by reshaping workless policy in this way, and by placing more onus on government and employers to deliver sufficient quantities of appropriate jobs, might a more equitable approach to ensuring that 'no one [is] written off' be achieved.

\section{Conclusion}

The welfare reform paper can be conceived of as a discursive project that frames the case for reform on the basis of three claims concerning motivation, morals and social justice. Drawing on Levitas' observation that discourses 'govern[] the paths of action which appear to be open to us' (2005: 3), it can be suggested that the claims deployed in the green paper appear to make a compelling case for intensifying the pace of supply-side welfare reform. Yet in shaping the 'paths of action', discourses also function to 'close down possibilities' (2008: 3) and this is no less true of NOWO. Not only does the paper ignore a well-established and, in the present economic climate, ever more urgent body of research 
on issues with a shortage of demand in the UK labour market, it also deals inadequately with concerns relating to the quality of work. Once these are taken into account, the discursive basis of the case for reform presented in the green paper becomes far less certain. The intensification of supply-side welfare programming seems misplaced if insufficient jobs exist. In addition, claims regarding the responsibilities of jobseekers as well as the social benefits delivered by work are undermined by questions about the quality of work available. In short, the discursive edifice begins to crumble.

Given this critique, it must be asked why these compelling challenges to policy orthodoxy have made so little headway. In answer, Peck (2001) makes a forceful case that welfare-to-work policies or, properly conceived, 'workfare' ensures the smooth functioning of neo-liberal economies. In particular, it enforces the acceptance of low-paid and contingent work that has emerged in the wake of economic restructuring:

Contemporary workfare policies...are...more concerned with deterring welfare claims and necessitating the acceptance of low-paid unstable jobs in the context of increasingly 'flexible' labor markets...workfare is not about creating jobs for people that don't have them; it is about creating workers for jobs that nobody wants'. (Peck, 2001: 6)

In other words, welfare policy seeks to expand labour supply to meet the requirements of contingent labour markets by disciplining more marginalised workers to take up low-paid or insecure forms of work (see also Jessop, 2002). In tandem with such forms of conditionality, the 'make work pay' agenda seeks to ameliorate conditions in the worst workplaces by making employment marginally more attractive. It could be argued, therefore, that policymakers are neither neglectful nor ignorant of labour market conditions but, rather, highly attuned to the nature of work in the lower end of the labour market. Workfare is a way of forcibly accommodating working-age adults to such conditions.

Conceived in this way, a discourse which seeks to shift the emphasis of responsibility onto workless individuals makes sense as it becomes an effective tool for legitimising conditional forms of welfare. As Bauman (2005: 68) has written elsewhere on discourses of poverty, castigating the poor and economically redundant for their own predicament serves to expel them from 'the universe of moral obligations' which compels governments to redress their plight. Similarly, it could be argued that the discourses deployed in the green paper allow both government and employers to abnegate their responsibilities for improving conditions in the lower end of the labour market. At the same time, these discourses validate policies to mould a workforce to the exigencies of a radically restructured labour market. In this way, the idealistic language of welfare reform with its appeals to motivation, morals and justice cloaks a rather less noble intent.

* Correspondence Address: Richard Crisp, CRESR, Sheffield Hallam University, Unit 10, Science Park, Howard Street, Sheffield, S1 1WB. Email: r.crisp@shu.ac.uk. 
p. 184. Motivation, morals and justice: discourses of worklessness in the welfare reform green paper

\section{Bibliography}

Alcock, P., Beatty, C., Fothergill, S., Macmillan, R. and Yeandle, S. (2003) Work to Welfare: How Men Become Detached from the Labour Market. Cambridge: CUP.

Bauman, Z. (1998) Work, Consumerism and the New Poor. London: OUP.

Beatty, C. and Fothergill, S. (2003) 'Incapacity Benefit and Unemployment' In: Alcock, P., Beatty, C., Fothergill, S., Macmillan, R. and Yeandle, S. (2003) Work to Welfare: How Men Become Detached from the Labour Market. Cambridge: CUP.

Beatty, C. and Fothergill, S. (2006) Moving older people into jobs: Incapacity Benefit, Labour's reforms and the job shortfall in the UK regions. Sheffield: CRESR.

Beatty, C., Fothergill, S. and Macmillan, R. (2000) A theory of employment, unemployment and sickness. Regional Studies, 34, 7, 617-630.

Black, C. (2008) Dame Carol Black's Review of the health of Britain's working age population: Working for a healthier tomorrow. London: TSO.

Blair, T. (1997) Speech at Aylesbury Estate. London, 2nd June.

CPAG (2008) Employers: the 'black hole' in ensuring no one is written off [online], press release, 21 st July 2008, accessed October $10^{\text {th }} 2008$, available at http://www.cpag.org.uk/press/210708.htm.

Cooke, G. and Lawton, K. (2008) Working out of poverty: A study of the low paid 'working poor'. London: IPPR.

Dean, H. (2007) The ethics of welfare-to-work. Policy \& Politics, 35, 4, 573-89.

Dickenson, R. and McKnight. A (2008) The Impact of Policy Change on Job Retention and Advancement, Case Paper 134. London: LSE.

Driver, S. and Martell, L. (1998) New Labour: Politics after Thatcherism. Cambridge: Polity Press.

DSS (1998) Welfare reform focus files: The case for welfare reform. London: DSS.

DWP (2002) Helping People into Employment. London: TSO.

DWP (2004) Building on the New Deal: local solution meeting individual needs. London: TSO.

DWP (2006) A New Deal for Welfare: empowering people to work. London: TSO.

DWP (2007) In work better off: Next Steps to Full Employment. TSO: London.

DWP (2008a) No One Written Off: Reforming Welfare to Reward Responsibility. London: TSO.

DWP (2008b) More support, higher expectations: the role of conditionality in improving employment outcomes. London: TSO.

DWP and DIUS (2008c) Ready to Work, Skilled for Work: Unlocking Britain's talent. London: TSO.

DWP (2008d) Transforming Britain's Labour Market: Ten years of the New Deal. London: TSO.

Fothergill, S. and Wilson, I. (2007) A Million off Incapacity Benefit: how achievable is Labour's target? Cambridge Journal of Economics, 31, 5, 1007-24.

Gallie, D, Marsh, C. and Vogler, C. (1994) Social Change and the Experience of Unemployment. Oxford: Oxford University Press.

Gray, A. (2004) Unsocial Europe: Social Protection or Flexploitation. London: Pluto Press.

Grieve Smith, J. (2005) 'Benefit cuts do not create new jobs' [online], The Guardian online, published 26th May 2005, accessed 30th September 2008, available at: http://www.guardian.co.uk/politics/2005/may/26/labour.socialexclusion.

Hopkins, K. (2008) 'Bank of England's Sentance spells out warning of 'severe' recession' [online], The Guardian online, published 13th October 2008, accessed 15th October 
p. 185. Motivation, morals and justice: discourses of worklessness in the welfare reform green paper

2008, available at: http://www.guardian.co.uk/business/2008/oct/13/economicsbankofenglandgovernor.

HM Treasury (2003) Full Employment in Every Region. London: HMSO.

Jahoda, M., Lazarsfeld, P. and Zeisel, H. (1933/72) Marienthal: the Sociography of an Unemployed Community. London: Tavistock.

Jessop, B. (2002) From Thatcherism to New Labour: Neo-Liberalism, Workfarism and Labour Market Regulation, published by the Department of Sociology, Lancaster University, originally made available online at http://www.lancs.ac.uk/fss /sociology//soc131ri.pdf [accessed Jan 2003, no longer available online].

Lash, S. (1994) 'Reflexivity and its doubles', In: Beck, U. Giddens, A. and Lash, S. (1994) Reflexive Modernisation; Politics Tradition and Aesthetics in the Modern Social Order. Cambridge; Polity Press.

Lash, S. and Urry, J. (1987) The End of Organised Capitalism. Cambridge: Polity Press.

Levitas, R. (2005) The inclusive society: social exclusion and New Labour. Basingstoke: Palgrave Macmillan.

Lodomel, I. and Trickey, H. (eds) (2001) An Offer You Can't Refuse: Workfare in International Perspective. Bristol: Policy Press.

McDowell, L. (2003) Redundant masculinities: Employment change and white working class youth. Oxford: Blackwell.

Midgley J., Stewart, K., Piachaud, D. and Glennerster, H. (2008) Welfare Reform in the United States: Implications for British Social Policy, CASE paper 131, April 2008. London: CASE.

Peck, J. (2001) Workfare States. New York: Guildford University Press.

Peck, J. and Theodore, N. (2000) 'Work first': workfare and the regulation of contingent labour markets. Cambridge Journal of Economics, 24, 1, 119-38.

Peck, J. and Theodore, N. (2000) Beyond 'employability'. Cambridge Journal of Economics, 24, 6, 729-49.

Mulheirn, I. and Menne, V. (2008) The Flexible New Deal: Making it Work. London: The Social Market Foundation.

Sunley, P., Martin, R. and Nativel, C. (2001) Mapping the New Deal: local disparities in the performance of Welfare-to-work. Transactions of the Institute of British Geographers, 26, 484-512.

Theodore, N. (2007) New Labour at work: long-term unemployment and the geography of opportunity. Cambridge Journal of Economics, 31, 6, 927-939.

TUC (2008) Hard Work, Hidden Lives: The Short Report of the Commission on Vulnerable Employment. London: TUS.

Turok, I. and Edge, N. (1999) The Jobs Gap in Britain's Cities: Employment Loss and Labour Market Consequence. Bristol: Policy Press.

UK Parliament (1999) Evidence of a geographical jobs gap. Select Committee on Education and Employment, Fourth Report.

Warhurst, C. and Thompson, P. (1998) Workplaces of the Future. Basingstoke: Macmillan Press.

Warr, P. (1987) Work, Unemployment and Mental Health. Oxford: Oxford University Publications.

Webster, D. (2006) Welfare Reform: Facing up to the Geography of Worklessness. Local Economy, 21, 20, 107-116. 